\title{
Improving Syntax Learning Achievement throughLesson Study Based Learning on IV Semester Students of Indonesian Language and Letter Education Study Program Pakuan University
}

\author{
Tri Mahayani ${ }^{*}$, Suhendra $^{*}$, Siti Chodijah ${ }^{*}$, Ainiyah $^{*}$ \\ ${ }^{*}$ Universitas Pakuan, Bogor, Indonesia \\ Corresponding Author: trimahayani68@yahoo.co.id
}

\begin{abstract}
The aim of this research is to know the process of Lesson Study based learning and the improvement of sytaxis learning achievement through Lesson Study based learning on IV semester students of Indonesian Language and Letter Education Study Program Pakuan University. This research is desgined as action research with lesson study based. There are four cycles used in this research. Every stage on lesson study cycles comprise of plan, do, see. The data colleted is analyzed using descriptive qualitative method. The result of the research shows that lesson study based learning process gives a wide opportunity, both to the lecturer and students to innovate, enhance activity, creativity, communication, and interaction during learning process. Collbaorative learning using various strategies, method, technique and media can focused the students in learning and understanding knowledge. It is relevant to be applied in syntactic learning where students discuss the events of concreat and contextual language use. Based on the observation result, the observers agree to the application of lesson study based learning. Students' response are also positive towards the lesson study based learning, which can be stated that students are more interested in learning using lesson study based learning. Students' syntax learning achievement shows an improvement, average score for posttest in first cycles 68,78 , average score insecond cycle is 77,45 , average score in third cycle is 78,15 , and average score in fourth cycles is 80,52 . Therefore it can be concluded that there is an improvement on syntaxis learning achievement through lesson study based learning on IV semester students of Indonesian Language and Letter Education Study Program Pakuan University.
\end{abstract}

Keywords: Lesson Study, learning achievement, Syntaxis.

\section{INTRODUCTION}

Language is a means of communication among members of society. Communication can be done through written and oral. In written form, to make communication effective, a writer must convey the messages properly to the reader. Messages can be convey properly if a writer can construct grammatical structure of sentences systematicly and meaningful. The study of sentence structure is called syntax.

According to Chaer (2009), syntax is a language subsystem that studies words arrangement and setting into bigger unit. Syntax unit are, words, phrases, clauses, sentences, and passages. On the other hand according to Syamsuddin (2007), Syntax or also called the study of words order describes the relation between language elements to form a sentence.Every element in syntax understood through its function in a system. The function of a syntax unit occurs if the unit appears in a formation, for example words formation in a phrase, phrase formation in a clause, clause formation in a sentence. Therefore it can be concluded that syntax is part of the grammar that discuss about sentence form, clause, and phrase.

Many forms of language indeed are part of sentence, clause, and phrase. Some linguists have define sentence, clause, and phrase. According to Alwi et.al. (2003), sentence is a smallest unit of a language, whether written or oral, that express complete thought. Effendi states (2015),clause is a unit of subject and verb and can form a bigger unit. Chaer said that (2000), phrase is a combination of two words or more serves as a unit, and included as one element of sentence function. The study of sentence, clause, and phrase is part of the discussion in syntax.

Syntax is one of lecture that needs to be studied by the fourth semester students of Indonesian Language and Letter Education Study Program. Syntax has to be learned because it relates to everyday communication in using written form, especially in learning process. In learning process, students' learning achievement is still considerably low because syntax is a difficult field to study. Students are still having difficulties in constructing structured sentence based in a pattern of Subject, Verb, Object and Adverb. 
Students are still unable to arrange words into proper and coherence sentence which in turn make it difficult for reader to understand. It affected on the low achievement which also affected the low ability in writing scientific paper. Students need to learn more. It is supported by Slamento's opinion (2015) which emphasize that learning is a process done by someone to obtain a change in behavior as a result of his own experience in interacting with the environment. Syntax learning process will affect students learning achievement. According to Asep (2012), learning achievement is ability obtain by children after undergoing learning activity. Therefore, through learning students will obtain a better learning achievement. Students will get more knowledge, supported with the interaction with the environment to gain more experience.

The cause of low learning achievement in syntax due to the uninnovative selection of method, strategy, technique, and learning media. The selection of strategy, method, technique, and learning media for syntax must be adjusted with the level or grade of the students and lecturers ability in classroom management. Both factors need to be concerned so the learning process can be conducted effectively and effeciently, especially in syntax.

Syntax is chosen as lesson study program expansion. Lesson study consists of three main stages, they are plan, do, and see, that is a formaly integrated learning process to create fun atmosphere through variative learning process.Lecturer together with students create an active, creative and innovative learning process so that students can learn more focus, get more understanding and can enjoy more syntax learning process in a classroom as fun learning activity. The application of strategy, method, technique and media in lesson study based learning is expected to improve students' syntax learning achievement. That particular learning can give more free space and opportunity to students to learn more active and creative whenever and wherever they are, yet still under guidance. Based on those ideas mentioned above, the researcher conduct research about learning syntax entitled, "Improving Syntax Learning Achievement Through Lesson Study Based Learning On IV Semester Students Of Indonesian Language And Letter Education Study Program Pakuan University."

\section{RESEARCH METHODS}

The aim of this research is to know learning process of lesson study and the improvement of syntax learning achievement through lesson study based learning on fourth semester, Indonesian Language and Letter Study Program, Pakuan University Bogor.

This research is conducted to the fourth semester Indonesian Language and Letter Study Program, Pakuan University Bogor. The total number of students in class A is 30 students, class B is 30 students, class C is 30 students, and class D is 30 students.

There are four lecturers conducting syntax learning with lesson study based. The first cycle was conducted on Thursday, 9 April 2015, lectured by Suhendra.The second cycle was conducted on Thursday, 16 April 2015, lectured byAiniyahEkowati. The third cycle was conducted on Thursday, 23 April 2015, lectured bySitiChodijah. The fourth cycle was conducted on Thursday, 30 April 2015, lectured by Tri Mahajani. Each cycle last about 2 X 50 minutes.Learning process took place at ordinary classroom.

According to Lewis (2012), Lesson Study exercise lecturers' profesionality in teaching. Lecturers are taught how to collaborate in arranging plan, applying it, and evaluate it. The result of the evaluation is then used as a reference for the next learning process.

Every cycle of lesson study is done in three stages; they areplan (making preparation), do (activity), and see (doing evaluation). On planstage, collaboratively lecturers planned a student's center learning process using problem based. On 'do'stage, lecturers enganging a students center activit, while other lecturers observing students activity. On'see' stage, lecturers collaboratively reflecting the learning process effectivity. Those three stages in one cycle is done continualy.On the reflection stage, data gained through observation is analyzed in every cycle. The result of the analysis is used an evaluation and reference for the next cycle.

\section{RESULTS AND DISCUSSION}

\section{Data From Observation Result in Cycle 1, Cycle 2, Cycle 3 and Cycle 4}

Observation is done during syntax learning process. Observation is used to knowstudents' attitude and behavior toward learning process conducted by lecturer. In conducting the observation lecturers are assisted by fellow lecturers from Indonesian Language and Letter Education Study Program. The result from observers' questionnaire on cycle 1,2,3, and 4are shown in the chart Figure 1.

\section{Data Result from Students' Response}

Students' response is used to describe how students respond during syntax learning process. From the questionnaire result, students give positive response toward syntax learning process conducted by the lecturer. Students attended the lectur on cycle 1, students from class A are 20 students, cycle 2 class B are 27 students, cycle 3 classCare 27 students, cycle 4 class D are 27 students.

Lesson study learning process gives a wide opportunity, both to lecturer and students to innovate, improve activity, creativity, communication, and 
interaction in syntax learning process. It is very relevant to be applied on syntax learning processes that discuss concrete and contextual language events.

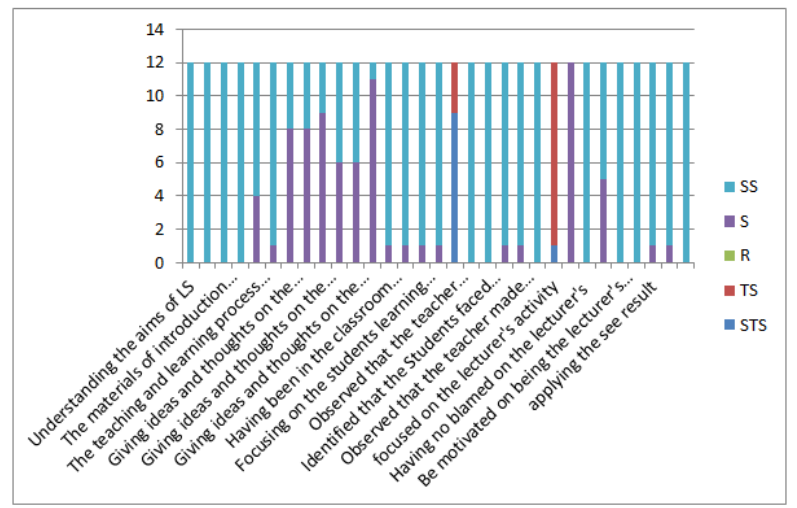

Figure1. Result of Observers' Questionnaire Syntax Open Lesson Cycle 1, 2, 3, dan 4

Based on observation result, observers agree on the application of lesson study based learning.Students response are also positive toward lesson study based learning, it means that students are more interested in learning using lesson study based learning. Questionnaire result on students' response on cycle $1,2,3,4$ is shown by the chart figure 2 .

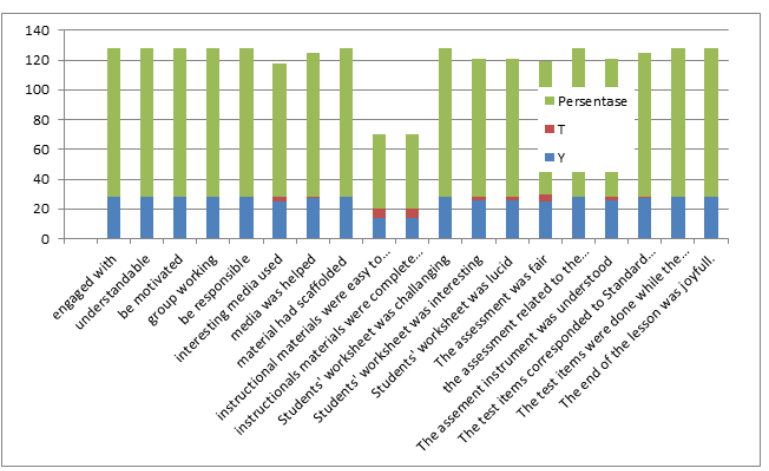

Figure 2. Questionnaire Result on Students' Response on Syntax Open Lesson Cycle 1, 2, 3, 4

\section{Syntax Postetst Result on Cycle 1,2,3,4}

The application of lesson study can improve syntax learning result on fourth semester students Indonesian Language and Letter Education Study Program Pakuan University. The improvement can be seen from posttest average score in cycle 1 which is 68,78 , cycle 2 average score 77,45, cycle 3 average score 78,15 , and cycle 4 average score 80,52 . Students' posttest result on cycle $1,2,3,4$ is shown by the following chart figure 3 .

\section{Research Result Discussion Cycle 1,2,3,4}

Research result discussion covers the discussion of students' observation result, students' response result, the conduction of plan, do, seeand students posttest result.

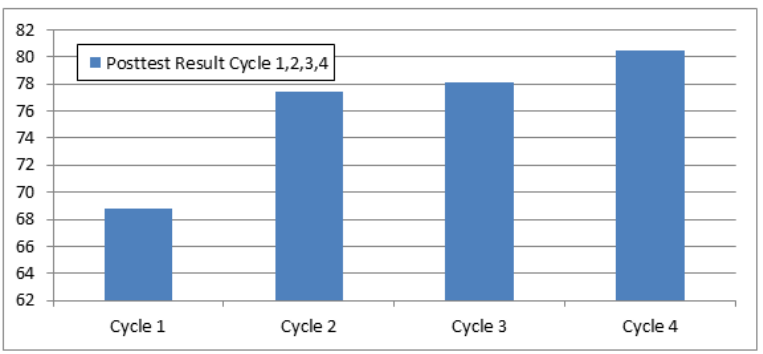

Figure 3. Postest Result on Cycle 1,2,3,4

\section{Observation Discussion on Students}

On cycle 1,2,3, and 4 the observation result stated that all observers are agree with the application of lesson study based learning. Observers generally understand about the aim of lesson study and its process.Material from socialication is very helpful for the students, lesson study can improve both students and lecturers' ability in conducting teaching learning process, learning process is more focus on problem solving. In this case observers also give advice in constructing the lesson plan, students worksheet, learning material, teaching strategy, teaching media, and observation sheet.

During the learning process observers were not intervening, stay in the room the whole time, did not talk to other observers. Observers focus observing learning process. Observers pay attention when students are given chance to discuss. During the teaching learning process observer noted that lecturer did not dominate the process, students are given opportunity to ask question, as well as identify students with learning problem.Lecturer was very helpful during the process, adjusting lesson plan with real situation, learning outcome is achieved.

Most of the observers agree that teaching learning process conducted by the lecturer has made students understand more easily about syntax. The application of various strategy, method, technique, and media during the process can give more focus and expand students' knowledge. Students' knowledge is expanded because they did a group discussion. Through discussion process students collaborate, asking each other questions, sharing ideas to expand knowledge, engange in exercise using worksheet prepared by lecturer. Students are allowed to present the result of their discussion, and being responded by other groups with lecturer's guidance. Even though syntax material is difficult but students can seem to understand better. Teaching learning become meaningful because students get more experience from the process so they are motivated to learn syntax.

After teaching learning process, observers give advice and comment based on their finding during the process. Observer doesnot judge lecturer during the 'see' stage instead they give valuable advice that can 
motivate and aspire lecturer to improve the lecture quality by applying the result from reflection stage.

\section{Discussion of Students' Response}

On Cycle 1, 2, 3, and 4, from the result of the questionnaire students are giving positive response towards all aspects of instruments and teaching learning process. Students enjoy and understand syntax learning process, students motivated to conduct syntax learning, students are able to cooperate and responsible with the task given. According to students statement the media used by the lecturer is very attractive and can help students in learning syntax. The material given is really helpful to solve the task given by the lecturer. Learning material for syntax is complete and simple. Students' work sheet is very challenging and interesting and can help students to understand more. The evaluation for syntax teaching learning process is already decided and the percentage of mastery is announced so that students know what to do. Evaluation is applied based on fix scoring criteria.

During teaching learning process lecturer give material step by step and using multiple media. Students expect that in learning syntax lecturer provide them with many examples so it will be easier for them to understand. Difficulties faced by students in learning syntax can be overcome by repeating the material and working the exercise. In order to understand the content of syntax material students are using sources from book and internet, also by discussing with peers, other than relying only from lecturer. Students feel enthusias because lecturer gives attention to their problem during the exercise. All and all students enjoy the process even more.

\section{The Discussion of Plan, Do, and See}

There are four model lecturers who are conducting syntax teaching learning with lesson study based. The first cycle of open lesson was conducted on Thursday, 9 April 2015, lectured by Suhendra, attended by nine observers. The second cycle of open lesson was conducted on Thursday, 16 April 2015, lectured byAiniyahEkowati, attended by six observers. The third cycle of open lesson was conducted on Thursday, 23 April 2015, lectured bySitiChodijah, attended by seven observers. The fourth cycle of open lesson was conducted on Thursday, 30 April 2015, lectured by Tri Mahajani, attended by six observers. Each cycle last about 2 X 50 minutes. Learning process took place at ordinary classroom.

\section{Cycle 1 discussion}

On planstage cycle 1 the team agreed to conduct the dostage. On planstagechapter design and lesson design about phrase are made, teaching media to be used is a piece of paper contains phrase an rhyme. Plan is conducted by four role lecturers.

Open lesson, cycle1. Discussing phrase was conducted nicely. The open lesson was started with proposing problem. Students are enthusiastic when discussing problem proposed by the lecture. It can be seen through students' ability to comment on the problem. The lesson carried on with a game of arranging jumbled words which consists of phrase. Students discuss and give question about the material. Before the end of learning process students are asked to do a posttest.Posttest runs smooths and order. The lesson ended by giving reflection together.

On seestage, there are some advices given by the observers, such as time allocation has to be adjusted with material complexity, change in media use, some students did not bring lesson material. The strength of this process is that media chosen is very contextual so that students felt more interested in learning the material, question and answer session happened actively and responsively.

\section{Cycle 2 discussions}

On planstage cycle 2chapter designsandlesson design about phrase are made. Teaching media to be used is news slide using both Indonesian and Malaysian.

The open lessonruns smooth. Open lesson syntax cycle 2discussing phrase is started with a slide of language use from Vicki also known as "Vickinisasi" in social media.In the slide shown there are language use by 'Vicki' which mostly incorrect both in diction and sentence arrangement. Students seemed enthusiastic reading the slide of this case. It can be seen on students' ability in giving comment on language use in the slide. After discussing in a group, each group was asked to report their result. This activity runs smooth because all of the groups pay attention to their friends' explanation. Next, the students were asked to do the posttest given by the lecturer. The lesson ended by giving reflection together.

On seestage, there are several advices given by the observers, they are students who did not prepare for the lesson, question and answer session did not run optimal, and time allocation did not match the material complexity. The strength of this cycle is discussion session took place very active, students felt enthusiastic in doing all stages of the open lesson; students enjoy learning media, words cards media give the students opportunity to think comprehensively. This advice is used as reference for the next cycle.

\section{Cycle 3 discussions}

On planstage in cycle 3the team agreed on several things to conduct do.Chapter design and lesson design were made during plan stage with clause as learning material. Article and advertisement from a magazine is going to be used as teaching media.

Syntax open lesson cycle 3 with caluse as the material is initiated with apperception, followed by the use of articale and advertisement from a magazine as the media. The students then analyzed clause from the media given. During discussion there is a group that 
seems to face difficulties in determining the category and role in clause. Students cannot differentiate clause from sentence, knowing they are having difficulties the group immedietly ask the lecturer about it. They continue the discussion after having clear explanation from the lecturer. Next, the students are asked to present their result. And then when all activites done, students do the posttest. The lesson ended by giving reflection together.

On see stage the observers give advice about the difficulties in arranging time management for all stages of lesson design, students are still found to be nervous during discussion, some off the students are not prepared. The strength of this cycle is that the media selected is very contextual so that students feel more interested in learning the material. Question and answer session run active and responsive. Open lesson is done with the best of preparation. The advice from the observers is used for the next cycle.

\section{Cycle 4 Discussions}

On cycle 4planstagescome up with several deals in conducting do. Chapter design and lesson design for sentence as material is done on plan stage. The media used in this cycle are random cards, pictures, and running text video clip.

Syntax open lesson cycle 3 with sentence as the material is started with game of arranging random words into meaningful sentence. Students are very enthusiastic and compete with each others. After finding the words the students then stick them on the board, and they are asked to analyze the sentence. When analyzing the sentence, students are having difficulties in determining the function of the sentence. This is overcome by the role lecturer. On the next part lecturer shows the students a running text and they are asked to write down one sentence from it. Student writes it on the board and their friends give comment to the analysis result. Students are very enthusiastic to give comment on the analysis result and beginning to understand the function of a sentence. Lecturer explains the material about sentence function with the problem faced by students. After finish discussing some groups are asked to present the result. This activity runs well because all students pay attention to their friends during the presentation. After the process finish, students were asked to do a posttest, which were orderly done. Teaching learning process ended with reflection which was done together.

On 'see',stage advice given by the observer were; the difficulties in arranging time distributionon each stage of activity. Students' work sheet is too difficult. The strength of this process are the media chosen were very contextual and variative so that students feel more interested in learning, teaching learning process with problem based, question and answer session was active and responsive, open lesson was conducted with the best preparation.

\section{Syntax Posttest result Cycle 1,2,3,4}

The process of lesson study gives freedom to students in doing activity and to be creative, it is very relevant to be applied on syntax learning processes that discuss concrete and contextual language events. Lesson study learning process gives a wide opportunity, both to lecturer and students to innovate, and create learning material and learning media. Beside that, through lesson study lecturers and students can have more opportunity to innovate, improve ctivity, creativity, communication, and interaction during learning process.

Based on posttest result there is improvement on students' learning achievement. The improvement can be seen from posttest average score in cycle 1 which is 68,78 , cycle 2 average score 77,45 , cycle 3 average score 78,15, and cycle 4 average score 80,52.

\section{CONCLUSION}

Lesson study learning process that is conducted through plan, do, seestage can create an innovative learning process.Collaborative learning by applying various strategy, method, technique, and media during learning process can help students to be more focus in learning and students can explore their knowledge. Through lesson study, lecturers and students can have more opportunity to innovate, improve ctivity, creativity, communication, and interaction during learning process. It is very relevant to be applied on syntax learning processes that discuss concrete and contextual language events. Based on observation result, observers agree on the application of lesson study based learning. Students response are also positive toward lesson study based learning, it means that students are more interested in learning using lesson study based learning.

Based on posttest result there is improvement on students' learning achievement. The improvement can be seen from posttest average score in cycle 1 which is 68,78 , cycle 2 average score 77,45 , cycle 3 average score 78,15, and cycle 4 average score 80,52.Therefore it can be concluded that there is an improvement on syntax learning achievement through lesson study based learning on IV semester students of Indonesian Language and Letter Education Study Program Pakuan University.

\section{REFERENCES}

Alwi, Hasan, dkk. 2003. Tata Bahasa Baku Bahasa Indonesia. Jakarta: Balai Pustaka

Chaer, Abdul. 2000. Tata Bahasa Praktis Bahasa Indonesia. Jakarta: Rineka Cipta

Chaer. Abdul. 2009. Sintaksis Bahasa Indonesia. Jakarta: Rineka Cipta

Effendi, 2015. Tata Bahasa Acuan Bahasa Indonesia. Tangerang: Pustaka Mandiri 
Haris, Abizar. 2017. Buku Master Lesson Study. Yogyakarta : Diva Press

Jihad, Asep. 2012. Evaluasi Pembelajaran. Yogyakarta: Multi Presindo

Syamsuddin. 2007.Modul Struktur Bahasa Indonesia. Bandung: SPS UP

Slamento, 2015. Belajar dan Faktor-Faktor yang Mempengaruhi. Jakarta: Rineka Cipta 